\title{
Story-Building for Revolution: Post-Marxist and Neo-Nationalist Perspectives on the Yellow Vests Movement
}

\section{O 'Story Building' de uma Revolução: Perspetivas Pós-Marxistas e Neonacionalistas sobre o Movimento Coletes Amarelos}

\author{
Rodrigo Almeida Sousa \\ CITCEM, University of Porto
}

\begin{abstract}
On 17 November 2018, hundreds of thousands of French joined in protest against the ecological tax rise on hydrocarbons announced by Emmanuel Macron. The Yellow Vests phenomenon had been born. Since then, it has been active for several months and there seems to be no end in sight. As the movement began to get organized, it created websites and pages on social media, producing a challenging storytelling based on more than 40 demands and 25 proposals for the crisis. Thus it gave voice to the middle and middle-lower classes, which are deeply dissatisfied with their present socioeconomic conditions. Naturally, this narrative appealed to the extremist parties, from Mélenchon's radical left to Marine Le Pen's neo-nationalist right, as they immediately declared their support for the cause. Shortly afterwards, it was time for the intellectuals to manifest their views. On one hand, post-Marxists such as Slavoj Žižek and Antonio Negri wrote their articles on the subject. On the other, Russian nationalists, from leftist Boris Kagarlitsky to traditionalist Aleksandr Dugin, did not hide their enthusiasm about the movement either. For, in fact, all these intellectuals have something in common: they all are story-building for revolution.
\end{abstract}

Keywords-Mass protests, Far-left, Far-right, Post-Marxism, Neo-nationalism.

Resumo-A 17 Novembro 2018, centenas de milhares de franceses aderiram ao protesto contra a subida da taxa ecológica sobre os hidrocarbonetos anunciada por Emmanuel Macron. Nascia, assim, o fenómeno dos coletes amarelos, o qual tem perdurado ao longo de vários meses e parece não ter fim à vista. À medida que o movimento se foi organizando, criou websites e páginas em redes sociais, produzindo um 'storytelling' de carácter reivindicativo com base em mais de 40 exigências e 25 propostas para a crise; o qual dava voz a um clima de profunda insatisfação quanto à situação socioeconómica em que vivem as classes média e média-baixa. Claro está que esta narrativa agradou aos partidos extremistas, desde a esquerda radical de Mélenchon à direita neonacionalista de Marine Le Pen, que imediatamente declararam o seu apoio à causa. Pouco depois, era a vez dos intelectuais se manifestarem. De um lado, destacaram-se os artigos dos pós-marxistas Slavoj Žižek e Antonio Negri. Do outro, os nacionalistas russos, desde o esquerdista Boris Kagarlitsky ao tradicionalista Aleksandr Dugin, tampouco esconderam o seu entusiasmo quanto ao movimento. Com efeito, todos estes intelectuais têm algo em comum, já que todos contribuem para um 'story-building' de cariz revolucionário.

Palavras-Chave-Protestos em massa, Extrema-esquerda, Extrema-direita, Pós-marxismo, Neonacionalismo.

Submitted-28-12-2018. Accepted-21-04-2019. 


\section{Introduction}

T AVING emerged in November 2018, the Yel1 low Vests movement has been one of the major sociocultural phenomena of recent decades, to the point of being compared to the events of May 1968 by many authors (Žižek 2018a; Negri 2018a). Lasting for several months and with no apparent end in sight, it has spread throughout France and could potentially disseminate across Europe; for, even though we cannot yet fully understand its political consequences, we can see how the movement has been organizing itself as an autonomous social agent, which seems to effectively promote a politically attractive crossmedia narrative (on TV, blogs, digital newspapers, websites and social networks), based on anti-establishment claims. The Yellow Vests have, therefore, represented with relative success the feeling of dissatisfaction shared by a great many French citizens, which, of course, has earned them the enthusiastic support of both far-left and farright parties, politicians and intellectuals. In this context, particularly regarding the latter, some questions arise: Who are these intellectuals, what do they openly think about the Yellow Vests, and for what reasons do they support them? In which discursive currents do they fit and how have they been contributing to the narrative body of this phenomenon? In other words, from their point of view, what is the conceptual and dialectical nature behind the whole yellow vest cross-media storytelling and subsequent story-building?

\section{Methodology}

In order to address these questions, we have used a hermeneutical, critical and comparative approach on the narrative body produced around the Yellow Vests, according to the following steps:

After a brief review of the situation, and considering that this movement has been encouraged by the most radical political-ideological

- Rodrigo Almeida Sousa, Integrated Researcher of Transdisciplinary Research Centre 'Culture, Space and Memory' (CITCEM), of University of Porto.

E-mail:mail_rodrigo@hotmail.com

DOI http://dx.doi.org/10.21814/perspectivas.329 spectra, we start by critically analyzing two emblematic far-left post-Marxist intellectuals who reacted promptly to the phenomenon when it first emerged, immediately declaring themselves as yellow vest supporters: Antonio Negri and Slavoj Žižek. Hence, we have primarily focused on their recent articles, and then related them with some of their most representative works - in the case of Negri, Empire (2001) and Multitude (2004), both co-authored with Michael Hardt. As for Žižek, we looked at First as Tragedy, Then as Farce (2009) and Violence (2008). We then established a comparative balance between the two authors, since they diverge in their prospects and proposed resolutions;

As far as the comparative approach is concerned, it has mainly been applied to alternative sociopolitical narratives, particularly considering their background and present context, from neonationalism to the far-right/alt-right movements. In this way, we sought to bring to light a heuristic exercise common to Kagarlitsky, Jean-Marie Le Pen, Marine Le Pen and traditionalists such as Aleksandr Dugin: the apparent rejection of the left-right spectrum accompanied by the paradoxical adoption of its most extreme elements and values. In this case, our comparative analysis was not limited to intellectuals, since both Kagarlitsky and Dugin are not mere scientific observers, for they take an active part in the political dynamics of Putin's regime.

Finally, as a hermeneutic object in the context of cross-media, we designate by 'storytelling' all the discursive action (stories, news, posts, tweets, memes, etc.), whose storyline directs the receiver from one medium to another (Antikainen et al. 2004, 7). Thus, we might call storytellers not only the original content producers/narrators (in this case, the Yellow Vests themselves), but also all interactive co-producers/co-narrators (e.g. intellectuals, political agents, journalists, common citizens/internet users), who contribute to such action. As for the term 'story-building', it signifies the narrative body of the phenomenon as a whole, which results from a potentially infinite discursive activity/interactivity and is always under construction. 


\section{Origin and status of the Yellow Vests phenomenon}

On 17 November 2018, approximately 280,000 people gathered in protest against the rise of fuel prices all over France, from the most distant provinces to the Élysée Palace in Paris (BBC 2018). The Yellow Vests movement was born. The impact was immediate and conclusive, with one dead, 227 injured and 52 arrests (ibid.). The country was blocked, came to a standstill and the whole of Europe stopped to watch. However, given the size of the crowd, we can consider the demonstrations to have been relatively peaceful, having occurred almost without incident in most areas (ibid.).

During the 12 months prior to the demonstrations, the price of diesel, the most commonly used fuel in France, rose by $23 \%$, to an average of 1.51 per liter, the highest it had been since the beginning of the 21st century. Even though there was a slight fall in international oil prices at the end of the year, Macron decided to increase the rate on hydrocarbons by 7.6 cents/liter on diesel and 3.9 on gasoline. With the polls showing levels of public discontent reaching $70 \%$ (ibid.), this measure provoked a chain reaction on social media, and it was the last straw for outraged citizens, who put on their yellow vests and took over the streets. Indeed, it was consensual in the media coverage that this movement was born spontaneously, standing out as a protest of multitudes, without political or partisan intermediation (Negri 2018a).

However, the reaction from the parties did not take long. From the Republicans, Laurent Wauqiez appealed to Macron to postpone the controversial tax. As for the Socialists, after the humiliating results in the 2017 election, their new leader found himself in a delicate position, so he was subtle and ambiguous. On the one hand, Olivier Faure had to react with the appropriate moderation of a Social Democrat. On the other, he could not counteract such a multitude, whose discontent represented more than two-thirds of the French people. In a remarkable gesture of rhetoric juggling, Faure was able to simultaneously emphasize the non-partisanship of the movement, point to the need for the political class to listen to the people, and recognize the protesters' right to fight for the improvement of their purchasing power and tax justice (BBC 2018) - all without committing to anything or anyone.

The explicit support for the Yellow Vests came from the extreme political spectra. The President of the National Rally, Marine Le Pen, was one of the most outspoken personalities, not only approving but also encouraging the protesters to express their anger in a peaceful way. However, without a doubt, the most effusive support came from the left. The day after the protests, Jean-Luc Mélenchon (2018), gave an enthusiastic speech about the new France that was emerging; and since then, via his blog (L'Ére du Peuple), the leader of Unsubmissive France has been following the protesters step by step and is full of praise for them. Indeed, the agreement shown by the more extreme political factions in relation to the Yellow Vests is a sign that citizens' discontent goes far beyond a mere disagreement over the price of fuel or the ecological tax that has caused it. For what really is at stake is the distancing of the dominant political class, which Macron represents, to the real problems that the middle and lower classes face daily, particularly in rural France (BBC 2018). In fact, this is why the 'yellow vest' has become a symbol for the movement, since it is precisely this prop that the common driver uses to draw attention in case of emergency or road accident.

Meanwhile, it has been a few months since the movement began and, naturally, its narrative has gained consistency, mobilizing the citizens and arousing in them the will to fight for their interests (not only bureaucratic rights), and completely change the society they live in. The issues have multiplied. Today, the Yellow Vests are struggling for over 40 issues accompanied by 25 proposals (Bleu 2018). Moreover, they have clearly improved their coordination and strategic communication. Based on a very appealing concept ('by the people and for the people'), and inspired by the principles of participatory democracy, the movement has been successfully spreading its message through a network of online platforms (websites, applications, podcasts), combined with a well-designed and articulated structure of influence, both nationally and internationally (Gilets Jaunes 2019). 
What we may call the yellow vest cross-media storytelling has been developing notoriously well, generating a remarkable involvement of their inner circle, political supporters and a significant part of the French people - all this without altering the basic structure of their primary narrative, essence and authenticity. Hence, it becomes inevitable to ask: what really constitutes this essence? On one hand, since the movement remains true to its origins, it is only by answering this question that we can actually understand it. On the other, however, this implies broadening our focus of analysis, projecting it beyond the subjective narrative provided by the Yellow Vests' institutional storytelling. That is to say, we have to take into account the whole story-building that, since November 2018, has been constructed around this phenomenon, in order to select the most defining characteristics. Therefore, we will focus particularly on what has been said and written by the intellectuals, from both extreme political spectra, who expressed their explicit support for the movement; beginning with the postMarxists, Antonio Negri and Slavoj Žižek.

\section{Antonio Negri and the 'dual power' of the 'multitude'}

In his article published on the Euronomade website, on 4 December 2018, Antonio Negri begins his reasoning by bringing us into the social context leading up to the protests. Contrary to what socialist leader Olivier Faure had suggested, the Yellow Vests are not merely a movement of dissatisfied citizens complaining about bourgeois whims, such as lack of purchasing power or tax injustice (BBC 2018). If this were so, far from being superficial, the proposal of Republican Laurent Wauqiez would have made perfect sense to them. Consequently, simply postponing the new hydrocarbons tax (ibid.) would have been more than enough for all those demonstrators to immediately put away their vests and return to their homes. But the early reactions of the French moderate parties only confirmed the criticism and blame they share with Macron for the gap between the rhetoric of the political classes and citizens' real problems. After all, one can only find $70 \%$ discontent in a society whose lower middle class is already learning what misery, precarity and desperation are about when paying the bills at the end of the month:

Certainly, in France there

is now a multitude that violently arises against the new misery (...) the reduction of the labor force to precarity (...) insufficient public services (...) savage taxation of social services (...) the coming attacks on the retirement regime and the financing of national education. In France, therefore, there is something that violently arises against this misery, and which is followed by the cry 'Macron, démission' (Negri 2018a)

There is a clear difference between the Yellow Vests' protests and those of May 1968. What was at stake in 1968 was a global transformation of culture, as well as the position of a generation regarding its place in history and the role it intended to play in the contemporary world. According to Alex Callinicos, this resulted in a social-democratic synthesis, that is to say the tacit agreement between the revolutionary intellectuals and the ruling class (Callinicos 1989). In fact, this was the generation which gave rise to the new class of white-collar workers with increasingly specialized formal education (Drucker 2001), which has prospered both in financial terms and in quality of life, although it has not ceased to be subjected to global capitalism and consumer alienation (Callinicos 1989, 162-171). As for the Yellow Vests, they are in the opposite situation, precisely because they are losing everything that their predecessors had conquered, to the point where they now find themselves struggling against labor shortages and a kind of instability that for decades would have been unthinkable in the West. From Negri's perspective, there is something very peculiar about this movement's struggle, which not only differentiates it from May 1968 but also from any other precedent: 'It has a desperate face... it resembles a prison uprising rather than the mass workers' joy in sabotaging (the system).' (Negri 2018a).

As for the main target, it is Macron, of course. From the protesters' point of view, the French president symbolizes banking, global capitalism and the international financial system, which, to- 
gether with the parties of the regime, constitute what we may call the 'establishment'. And it has been precisely this establishment that the French have been trying most to get rid of, election after election, as long as they do not yield to the temptation of extremism. Nonetheless, their struggle has been inglorious and exhausting, especially after the Francois Hollande fiasco, whom in the final stage of his presidency could not even surpass $4 \%$ of popularity (Berdah 2016). The Yellow Vests are driven by a deep discontent with the system itself, as a whole. This peculiarly brings them very close to Antonio Negri's thoughts, for they are similar to what the author designates as a 'multitude', i.e. the living alternative that grows within the 'empire', against which it stands (Negri and Hardt 2001, xiii).

According to Negri we have, on the one hand, the empire of global capitalism, which diffuses its network of hierarchies and divisions, maintaining order through new mechanisms of control and constant conflicts (ibid.). Note, for example, the interminable military action ranging from Iraq to Afghanistan, which is only comprehensible in the light of the strategic, economic and political interests of a ruling class that stands above and acts transversally to the nation-states. In other words, a power superstructure composed of financial leaders, the military and energy oligopolies, among others, exercising its dominance through a web of political movements and circles, which interconnect on a global level. In effect, to some extent we all participate in the indomitable dynamics of this empire through our consumption, savings and investments (Savitz 2011). But of course, it is simply a statement of fact that wealth, economic and financial power have been concentrated in recent decades around a select group of multinationals and investment funds (Upbin 2011, Coffey 2011).

On the other hand, we have the 'multitude' which, according to the post-Marxist thinking of Negri and Hardt, transcends the 'working class' itself, and includes the poor in the widest sense, i.e. all those who do not belong to the ruling class, which is the reason why they are progressively becoming impoverished and losing their rights. Fortunately, in the West, we do not have millions of famine victims or 'damnés de la terre' (as the
International Anthem says). But there are certainly too many victims of globalization, several million poor whose socioeconomic condition has worsened day by day while they see their democratic power fleeing from their hands. Since power has increasingly been centralized in international decision-making poles, far from popular scrutiny and under the dominance of political-financial circles which lack transparency. As a result of this widespread discontent, spontaneous transnational movements emerge, assembling 'new circuits of cooperation and collaboration that extend across nations and continents and allow an unlimited number of encounters' (Negri and Hardt 2004, xiii). The protests of the multitude are thus the only current expression of authentic democracy, since it comes from the 'common' - the morphological and effective root of communism (Negri 2012), which peculiarly contrasts with the manipulative usage of the term 'democracy', adopted by the dominant classes as a rhetorical means to achieve their political and strategic ends (ibid.).

Notwithstanding, Negri tries to avoid excessive or premature optimism for the Yellow Vests, for there is something in this movement that still remains indecipherable (Negri 2018a). It lacks more coordination, more uniformity in its discourse and action. If the democratic expression of the multitude is not to be fragmented, or to become an instrument of the establishment itself, it must necessarily transform itself into an organization (ibid.). Preferably without forming a party, for the more independent the movement is, the more it can function as the organized dynamic of the multitude which, instead of holding power, imposes itself as counter power. In this manner, the Italian thinker particularly emphasizes what some post-Marxist theorists (Tronti, Hardt and Negri himself) designate as 'Autonomism' - a politicalphilosophical current that analyzes precisely how self-organized social forces emerge and how they struggle against the ruling class. However, to effectively become an autonomous movement the Yellow Vests cannot limit their struggle to the demand for labor rights and purchasing power, as that would result once again in the same socialdemocratic synthesis which only perpetuates the existing system. For Negri, it is only when the immense diversity of the excluded converge in 
the self-organized movement of the 'common' that it can truly constitute itself as 'multitude', consequently transforming the existing system by imposing itself as an active structural dynamic that we would call 'dual power' or 'power against power' (Negri 2018a, Negri 2018b). According to the author, the Yellow Vests movement is precisely at this stage, still indecipherable. For the time being, no paradigm revolution can be expected in the Western system, only the possibility of transforming its dialectical process through the emergence, structuring and consolidation of an effective counter-power made up of the multitude of the common.

\section{Slavoj Žižek and the paradigm rev- olution}

The way the Yellow Vests should organize themselves is a fundamental issue both for Negri and Žižek. If they line up with any of the political parties that support them, they will lose their independence (Negri 2018a) and the autonomy indispensable to self-organization - these qualities were actually emphasized by Mélanchon (2018) in his reaction to November 17. After all, the idea of a multitude that stands by itself against the whole system is typical of revolutionary glamour, both in its symbolic and psychosocial dimension, especially in France, the country of May 1968. Nonetheless, according to Slavoj Žižek (2018a), not only are the Yellow Vests indecipherable but they are still too inconsistent and contradictory to achieve effective self-organization, as is particularly evident in their proposals:

They offer an exemplary case of the leftist populism, of the explosion of people's wrath in all its inconsistency: lower taxes and more money for education and health care, cheaper petrol and ecological struggle... (Žižek 2018a)

More specifically, the movement proposes, on the one hand, to establish a maximum constitutional limit of $25 \%$ on tax collection and other contributions. But, on the other hand, it calls for a $40 \%$ increase in basic pensions and social benefits, a significant increase in public employment and the massive construction of 5 million homes for the homeless, as well as severe punishments for municipalities where there are people sleeping on the streets (Bleu 2018). As for the environment, the Yellow Vests demand pollution control and at the same time the reinforcement of reindustrialization. Moreover, in terms of international politics and defense, they propose nothing less than the exit from NATO and the FREXIT, beginning with the renunciation of the Treaty of Lisbon (ibid.):

The demands of the protesters aren't possible to implement within the current capitalist system - and they aren't ambitious enough to provoke a change to a more egalitarian, ecologically sustainable system either. (Žižek 2018a)

As might be expected, the contradictory and unrealistic nature of the Yellow Vests' demands, just as in most mass movements, mainly expresses tensions intrinsic to the multitude itself. But what can be stronger than all these differing tensions, to the point of aggregating the masses and leading them onto the streets, knowing that they will face police repression? Only a tremendous discontent, of course, accompanied with a sense of saturation with the current system as well as its cultural and socio-political patterns. In this manner, it is significant for Žižek that the protests have risen against the government's most politically correct measure - the ecological tax on hydrocarbons, i.e., a measure against global warming and climate change (Žižek 2018a). In other words, we are witnessing a profound dissatisfaction among the deep France, shared by $70 \%$ of the population, and which is leading peasants, rural workers and people from all over the provinces to invade the big cities.

Interestingly, Žižek has drawn attention to the inevitable emergence of phenomena such as these for many years. From the philosopher's point of view, at least since the crisis of 2007-2008, the flagrant irrationality of global capitalism (Žižek 2009, 81) can no longer disguise its ideological and illusory character (ibid. 9-77). The concentration of economic and financial power in the highest social spheres has created extremely serious and insurmountable divisions, especially between those who still have the capacity to enter (or remain) in the cycle of wealth and those who have 
simply been excluded from it and stand hardly any chance of being part of it again. This gap between the dominant minority on the one hand and the excluded multitude on the other has given rise to new forms of apartheid (ibid. 91), which are not restricted to the lower classes but are increasingly extending to the middle class itself (often designated as the white working class). Given this context, Žižek also shares Negri and Hardt's view on the current role of the 'common' (ibid. 86-94) as he calls for a new radical notion of the proletarian subject (ibid. 92). In addition, the 'rage potential' (ibid. 89) of these protesters should not be disregarded either, for they could feel justified to respond with subjective violence to the objective violence (Žižek 2008) perpetrated against them by a corrupt establishment that is constantly deceiving them with false rhetoric and failing them with fake solutions. After Hollande's resounding failure, the political banker Macron apparently symbolizes the last resource of this obsolete system and probably the best it has to give (Žižek 2018a, 2018b) - but of course, when the best seems not to be enough, the only true solution has to be radical, it must imply a paradigm shift. In effect, it is exactly at this point that the Slovenian philosopher diverges from Negri, for not only does he believe in the radicalism of this change but he is also firmly convinced that we already live in favourable circumstances to start implementing it. In this way, Žižek adds new possibilities to the ongoing story-building produced around the Yellow Vests phenomenon. More specifically, he provides us with two possible scenarios. In the first, the agents and structures of established power would be forced to negotiate. In the second and most unlikely set of events, the Yellow Vests themselves would take power.

As regards the first scenario, let us imagine that the EU would establish a historic agreement with a movement of this nature, that is, an efficient self-organized entity representing the multitude. In this case, the demands of the movement would have to be so radical that they would by themselves imply a paradigm revolution. To that end, they should focus exclusively on the effective resolution of 'primary contradictions' exactly in the sense in which Mao Tse-tung (1990, 154-229) used this expression - and simply put aside our 'secondary' divergences (ibid.). This is the heuristic exercise that Žižek (2018a, 2018b) suggests by recurring to the well-known Maoist distinction (primary vs secondary contradictions), for it is crucial to give up our contingent goals in exchange for surgical measures which are so substantial in nature that, at the instant they are implemented, will subvert the foundations of the system as we know it:

(Examples) What about the overhaul of our entire financial system, which would affect the rules of how credit and investments work? What about imposing new regulations which would prevent the exploitation of the third world countries from which refugees come? (Žižek 2018a)

As for the second scenario, the day a mass movement came to power, how could we deal with the chaos that would ensue? Faced with this possibility, Žižek reaffirms its radicalism once again. He argues that he is not afraid to give us a solution that is perhaps too similar to what we saw in the last century: the rise of an enlightened and regulating elite, implementing a kind of bureaucratic socialism (Kagarlitsky 2018) - the philosopher does not clarify whether this solution would be temporary or indefinite.

\section{The other side: Alternative narra- tives on the Yellow Vests}

Both Negri and Žižek view the issue of organization as central, for the success of the Yellow Vests depends on how capable they are of organizing themselves. On the one hand, it is only through self-organization that they can reach the levels of autonomy and independence that are necessary to attract multitudes of discontented people, so as to convert their 'secondary contradictions' into a single 'primary' goal (generic): change the status quo. On the other, however, self-organization can also have its disadvantages. If a self-organized movement is not solid enough, with regard to its strategy and pragmatics, as well as to its national and international dynamics and networks, it may become impotent (Negri 2018a) and be easily neutralized and/or absorbed by the established political system. There is, nonetheless, a question that Negri and Žižek seem to be avoiding: To what 
extent can we consider the Yellow Vests to be truly independent or politically disconnected (to the point of fearing their neutralization), if they have the explicit support of such relevant parties and personalities in French politics?

Based on the 2017 electoral results (Ministère de l'Intérieur), Le Pen's votes (21.3\%), added to those of Mélenchon (19.5\%), amount to no less than a $41 \%$ impact on the French electorate. These figures show us the huge influence of both far-right and far-left parties, cultures and networks in today's France, as well as the potential impact they might convey to any social-political movement once they publicly endorse it. In effect, whenever a political current explicitly supports a given cause, all those who sympathize or are somehow affiliated with that current (philosophers, academics, artists, journalists, opinion makers, influencers, associations, lobbies, NGOs, etc.), tend to directly or indirectly promote that cause and contribute to its political success.

In this way, the case of Portugal is particularly interesting, for it could serve as a hypothetical reference, in the near future, regarding the possible correlation between explicit party support and subsequent vitality of movements such as the Yellow Vests. Indeed, in Portugal we have, on the one hand, an almost irrelevant far-right and, on the other hand, a mildly influential Communist Party, which is supporting the parliamentary majority of the current Government. Can this be part of the reason why the Portuguese Yellow Vests have been a real failure (Pena et al. 2018) so far? What would happen if a populist or extreme right party, such as the CHEGA or the PNR, achieved an excellent result in the 2019 legislative elections? Or, perhaps a more realistic scenario, what could happen if the PCP were left out of the next majority? The Yellow Vests' struggle is ready and waiting to be used as a political instrument. In other words, should any of these scenarios happen, could this movement finally gain the explicit support of a relevant anti-establishment party in Portugal? And would this support then coincide with a sudden and supposedly unexpected rise of the Portuguese Yellow Vests?

The fact that French extremist parties are taking the protesters' side should not, therefore, be ignored or devalued. In addition to organized means and resources, political parties and currents are mainly sustained by a wider social and cultural discourse, which, of course, cannot be fully controlled by any particular institution or organization. Notwithstanding, there is an objective storyline to every sociopolitical phenomenon which can be deduced by analyzing its ongoing cross-media story-building. In this way, having already analyzed the contribution of Western postMarxists such as Negri and Žižek, we will now focus on the other side of the narrative. That is, on other intellectual agents who also support the Yellow Vests, not only including European farright populists but also Russian post-Marxists, neo-nationalists and traditionalists who allegedly maintain a privileged connection with Putin's regime, namely Boris Kagarlitsky and Aleksandr Dugin.

\subsection{Kagarlitsky's critical review on Slavoj Žižek}

Beginning with Boris Kagarlitsky (2018), his article on the spontaneous politics of the masses is, first of all, a criticism of Slavoj Žižek. In his perspective, the Slovenian philosopher is a paradigmatic example of European leftist intellectuals who were apparently astonished by the shocking emergence of the Yellow Vests phenomenon (ibid). In addition, the Russian author contradicts Žižek's (2018a) main argument by stating that the Yellow Vests' demands could actually be met within the present system; for most of these claims fall perfectly within the history of Western capitalism, especially in the European social model, and have already been fulfilled in the past (Kagarlitsky 2018). The problem is that all these social advances were abolished with the victory of neoliberalism (ibid.). Thus, only with the pressure of the masses on the dominant elites, who will repeatedly have to make concessions to popular discontent, can any social progress be achieved (ibid.), though always within the existing system and without the need to abolish capitalism (ibid.). Nonetheless, it is precisely at the heart of Kagarlitsky's critique of Žižek that we can recognize a curious detail: He seems to agree with the need for a constant and structural pressure on the elites by the discontent masses, 
assigning them a relatively similar role to what Negri (2018a, 2018b) designates as 'dual power' or 'power against power'.

However, the aforementioned agreement with Negri turns out to be only apparent, since, unlike the Italian philosopher, Kagarlitsky (2018) believes that we are dealing with what Leon Trotsky called a 'transition program'. In this respect, Žižek would be correct in stating that the Western economic and socio-political system has reached a critical point, although the solutions would not have to be so incisive or radical:

One can create effective state enterprises and use the profits for social needs. One can increase taxes on large corporations, or at least take away some of the tax benefits the transnationals enjoyed in almost all countries in the last decade. (...) One can stimulate economic growth and increase the wages (...) One may even finance social programs at the expense of budget deficit. (Kagarlitsky 2018)

In words other than those of the Russian author, we could therefore maintain certain capitalist pragmatics, as long as we altered the whole logic of prevailing Western capitalism and instead, perhaps, adopt some measures of the Russian model (e.g. large companies under state control). Now, what is this but a paradigm shift and an authentic revolution in the system? Kagarlitsky appears to be in complete disagreement with Žižek only to propose another radical transfiguration of the Western model - and precisely in accordance with a 'transition program', which seems not to be very different from the resolution of 'primary contradictions' - as opposed to 'secondary' ones (TséTung 1990, 154-229) - proposed by the Slovenian philosopher (Žižek 2018a, 2018b).

Let us not, however, discard the figure of Kagarlitsky, the 'Red Putinist' (Zadyraka 2015). Though his article turns out to be somehow incoherent and might cause some perplexity in Western left-wing philosophers, it engages in a kind of dialectic thinking which is quite characteristic of many present-day Russian intellectuals. Having a theoretical Marxist basis, Kagarlitsky integrates the dynamics and components of Marxism into the idiosyncratic capitalism of Putin's regime. In this way, he conciliates elements which, ideologically, can be situated both on the far-right and the far-left. And this, of course, is a very peculiar heuristic exercise to which we must give careful attention.

\subsection{From Le Pen to Dugin: Beyond left and right but against the center}

The combination of far-right and far-left elements is not new, neither in Russia nor in France, as far as political thinking and subsequent pragmatics are concerned. Since its beginning, this trend has been grounded in the profound rejection of both ideological spectra in its moderate version. More precisely, it started in the French sociopolitical context of the 1990s with the National Front's slogan 'Ni droite, ni gauche - Francais', inspired by a book with the same title written by Samuel Maréchal (1996), a prominent member of the party and Jean-Marie Le Pen's son-in-law. At the time when all those old guard nationalistic fantasies artificially constructed by European fascist and para-fascist regimes had become obsolete, new figures such as Le Pen began to re-clothe national sentiment in a more up-to-date and appealing way to discontented citizens. By the end of the decade, the National Front narrative was already well adapted to the growing process of the implementation of worldwide information technologies and what would become the global capitalism of the 21st century. Thus, just as multiple radical left movements began to rebel against the emerging global capitalism, so right-wing radicals saw this same phenomenon as an opportunity to reconquer their electorate, or perhaps, even expand their influence by persuading undecided voters and taking advantage of high abstention levels (IDEA 2019). In this way, they focused on capturing the interest of those dissatisfied with the status quo and, in particular, the working class, who, in the circumstances (e.g. lack of purchasing power or unstable employment), usually tends to fear immigration, openness to global markets and competition from countries with cheaper labor. The new far-right narrative was therefore addressed to all those who might be drawn to the idea that national sovereignties need to be vigorously defended and felt they could benefit 
from such policies, irrespective of their ideological spectrum. In the words of Maréchal, 'Instead of the interests of the left or the right, we prefer to fight for the interests of the French' (1996, 37). In the 21st century, it was Marine Le Pen who followed up on this strategy, developing it further and introducing the question of patriotism versus globalism:

We have entered a new bipartisanism. Bipartisanism between two mutually exclusive concepts that, from now on, will structure our political life. The cleavage no longer separates left and right, but globalists and patriots. (Le Pen 2015)

Nevertheless, among right-wing yellow vest supporters, Marine Le Pen is no longer the only party leader adopting this narrative. Today, as we are witnessing a rise of European neonationalism, many other populist leaders and related personalities are also calling for the rejection of right and left, while simultaneously appropriating the most extreme features of both political spectra. Thus, if on the one hand we have Negri and Žižek's post-Marxist left trying to capture the hope of the multitude, on the other hand, we are faced with an alternative sociopolitical culture which is far less known to the Western mainstream, but is equally emblematic of the times we are living in. As we gather together all the extremist narrative one can find, it becomes apparent that this very peculiar culture and political network has been mobilizing, since the early 2000's, adherents to all kinds of doctrines and ideologies, with a view to conquering those who are profoundly discontent with the current European ideals, society and political system:

New Resistance is an international network founded in North America, of National Revolutionaries, Patriotic Socialists, Populist Nationalists, National Bolsheviks, LeftNationalists, Right-Wing Anti-Capitalists, Eurasianists, Fourth Political Theorists (...). We are a nascent radical movement, a revolutionary nucleus. We look to Europe as the fount of our particular culture while respecting at the same time other nations, cultures and civilizations.

((Open Revolt n.d.)

In this way, all the mentioned narratives from the Le Pen of the 1990s to Marine Le Pen,
European populists, and the radical alternative movements - have a specific parameter in common, which we can express in the following proposition: 'Beyond left and right but against the center '(4pt). And where does this sentence come from? It is nothing less than the signature of The Fourth Political Theory official website (4pt), dedicated to the philosophical and political thinking of Aleksandr Dugin - the controversial Russian nationalist intellectual, former professor at Moscow State University and a former adviser to the Kremlin for more than 10 years. Often known as Putin's brain or Putin's Rasputin (Steinmann 2018), his real influence over the President of Russia is disputed by some analysts, including radical nationalists such as Anatoly Karlin (2017). However, what really matters in this case is not whether Dugin's influence has increased or diminished as far as institutional politics is concerned, but the actual effects that his philosophical thinking and cultural pragmatics have on European populism and worldwide farright/far-left neo-nationalist sociopolitical networks. Together with Eduard Limonov, Dugin was one of the creators of National Bolshevism, an ideology with a distinctive mark of its own, and which is typical of the new alternative nationalist culture he also helped creating, as it synthesizes the two major references for political extremism: Bolshevik communism and national-socialism.

Nowadays, Aleksandr Dugin (2013) is best known for his work, The Fourth Political Theory, and as a major figure of the Eurasian movement. As far as this theory is concerned, Dugin intends to implement nationalism against what he calls globalism, that is, the liberal democratic world order led and imposed by the United States. He defends a new order based on racial realism, for although no human race is superior to another, they all have fundamental and objective differences. As a geopolitical alternative to Western Unipolarism, he then proposes Multipolarism - a world organized in large spaces (Eurasia, China, North America, Europe, etc.), each one united by racial and cultural affinities. Moreover, Dugin professes freedom as an expression intrinsically linked to the collectivity, opposing it to individualism or mere individual freedom, for true freedom must be in part a collective phenomenon. With respect to 
our perception of time, he suggests going back to the cyclical timeframe or the eternal return, rather than perpetuating human submission to modern chronology and its ideology of progress. Finally, the pillars of this new world would be grounded in national sovereignty, traditional values and social justice.

Based on The Fourth Political Theory, Dugin's Eurasian movement is, therefore, the pragmatic extension of these radical ideals and one of the most relevant intellectual and sociopolitical networks behind the new alternative neo-nationalist culture of the 21st century. In short, this is the revolution that Putin's former advisor wants to carry out around the globe. And to do so, one must seize all radical doctrines, all the discontentment with globalization, and recruit all extremist right/left cultures and sociopolitical forces so as to destroy the center, that is, the western axiological, political and ideological modern consensus (human rights, democratic liberalism and individual freedoms). In this way, Dugin's (2018) fervent support for the Yellow Vests' cause does not come as a surprise. Once again, we are faced with the same recurrent paradigm: Both far-left post-Marxists and far-right neo-nationalist/populist intellectuals, together with all the affiliated ideological, cultural and sociopolitical networks on which they have an impact, have been contributing to the whole yellow vest story-building with a kind of narrative which is intrinsically and explicitly revolutionary.

\section{Conclusions}

Considering our analysis of the narratives produced by both post-Marxist and neo-nationalist intellectuals regarding the Yellow Vests phenomenon, we can draw the following conclusions:

Beginning with the contributions of postMarxists who support the movement, Antonio Negri's perspective clearly fits into the works he wrote with Michael Hardt and their notions of 'empire' and 'multitude'. The Italian philosopher sustains that if the Yellow Vests turn out to be an efficient self-organization, they might become a revolutionary structure, which he designates as 'dual power' or 'power against power'. Although the movement has not yet been structurally organized as such, it is in a good position to do so, and thus gather the multitude with a view to radically transforming the existing dialectic of power. In other words, by replacing the current pseudo-revolutionary dynamics (based on the negotiation of mutual bourgeois interests through social concertation), with an active, solid and effective counter-structure, a movement such as the Yellow Vests could, sometime in the future, make way for an unprecedented synthesis: The overthrow of the present 'empire' by the 'multitude', followed by the institutionalization of the 'common'. Not unexpectedly, though, this new synthesis does somehow resemble the old Marxist one, i.e., the dictatorship of the proletariat with a view to utopia - which, of course, would certainly change the system as we know it;

Still within the post-Marxist writers, Žižek diverges from Negri insofar as the Slovenian believes in the almost immediate possibility and feasibility of radically transforming the socio-economic and political paradigm in which we live, for capitalism is coming to an end. Žižek provides us with two possible scenarios. In the first, an organized movement such as the Yellow Vests could succeed if it were able to nullify all the secondary contradictions inherent in the multitude, in the status quo and in the dialectic of power itself, and instead focus exclusively on surgical primary changes (e.g. changing the financial system). This, of course, would subvert and bring down the Western capitalist paradigm as we know it. In the second scenario, if a mass movement of this kind simply took over power (for instance, in a country such as France, and with systemic effects on the entire West), chaos would probably ensue. However, the Slovenian philosopher seems not to be too concerned about this possible context, since this same chaos could be solved by implementing a bureaucratic socialism - we do not know whether provisionally or definitively. In this way, despite criticizing inconsistencies in the Yellow Vests' institutional narrative, Žižek suggests that by the social impact and corresponding media storytelling they generate, movements such as the Yellow Vests may eventually result in a radical, systemic and imminent transformation of Western societies. In fact, from Žižek's per- 
spective, global capitalism is already provoking a generalized socio-economic collapse - e.g., the emergence of new forms of apartheid $(2009,91)$, the increasing of 'rage potential' and subjective violence as a reaction to the system's objective violence (2008) - which favors the sudden outbreak of movements with the eventual ability to, at any moment, fulfill a paradigmatic revolution.

With respect to the leftist nationalist Kagarlitsky, his criticism seems to contradict the radical tendency of his fellow post-Marxists, Negri and Žižek (particularly the latter). However, in an effort to reconcile the Yellow Vests' demands with the capitalist system, the Russian author proposes a 'transition program' that ends up having some affinity with the resolution of 'primary contradictions' suggested by the Slovenian philosopher. After all, Kagarlitsky is by no means a herald of liberal capitalism. Instead, he suggests a fusion of socialist and capitalist characteristics under a kind of state intervention clearly more compatible with the Putin regime than with the West. Indeed, the implementation of anything like this in the West would also be the equivalent of a paradigmatic revolution, certainly as drastic as the first scenario proposed by Žižek. Notwithstanding, the attempt to reconcile opposing ideological elements (e.g. left/right, socialism/capitalism), is not exclusive to this particular neo-nationalist and postMarxist Russian author, but is part of a broader alternative political culture.

As far as the far-right support for the Yellow Vests, it is mainly an extension of a narrative already used by the National Front in the 1990s. Rejecting both left and right, Jean-Marie Le Pen's rhetoric brought together extreme characteristics of both political spectra, turning them into political and ideological instruments at the service of nationalism. Following her father's steps, Marine Le Pen also puts French patriotism above any other ideological or political value, opposing it to globalism. Finally, among the most fervent supporters of the Yellow Vests, we come across Russian neo-nationalist intellectuals such as Aleksandr Dugin. As the basis of an entire alternative culture in vogue in Europe and the United States, the ideological project of Putin's former advisor is so radical that it involves nothing less than the end of the world as we know it. It is the most pro- found geopolitical revolution of our times, which seeks the global implementation of The Fourth Political Theory, based on the principles of national sovereignty and axiological traditionalism. Should the Yellow Vests suddenly begin to promote antiemigration measures or to defend any kind of racial supremacy, this could mean that at least one or more of these neo-nationalist political currents and socio-cultural networks have a greater influence on them than one might think.

Thus, we may finally conclude that all the above-mentioned intellectuals, as well as the ideological, socio-cultural and political currents to which they are affiliated, highlight and praise the revolutionary potential of the Yellow Vests. In effect, these same intellectuals and political actors also play a major role in contributing to the story that is being told and is being built around the movement, precisely reinforcing its radical, insurrectionary and potentially transformative character. In other words, all those who prominently develop or narratively interact with this phenomenon appear to be story-building for a revolution, or for what they believe to be a better world. This is exactly why, even if this specific movement disappears, another can fill its place, providing once again a voice to all the extremist currents and subversive cultural networks that aspire to the transfiguration of the West.

\section{References}

[1] 4pt. n.d. "The Fourth Political Theory: Beyond left and right but against the center." Last accessed March 9, 2019. http://www.4pt.su/en

[2] Antikainen, Hannele, Sonja Kangas, and Sari Vainikainen. Antikainen. 2004. "Three Views on Mobile Cross Media Entertainment (Report)." VTT Information Technology. https://www.vtt.fi/inf/julkaisut/muut/2004/ crossmedia entertainment.pdf

[3] Berdah, Arthur. 2016. "Popularité: à $4 \%$ de bonnes opinions, Hollande touche le fond." Le Figaro, October 25. http://www.lefigaro.fr/politique/le-scan/2016/10/25/ 25001-20161025ARTFIG00143-popularite-a-4-de-bonnesopinions-hollande-touche-le-fond.php.

[4] Bleu, France. 2018. "Demands of France's yellow vests as uploaded by France Bleu, November 29." OpenDemocracy, December 7. https://www.opendemocracy.net/caneurope-make-it/france-bleu/demands-of-frances-yellowvests-as-uploaded-by-france-bleu-november-29

[5] Callinicos, Alex. 1989. Against Postmodernism: A Marxist Critique. Cambridge: Polity Press.

[6] Coffey, Brendan. 2011. "The Four Companies That Control the 147 Companies That Own Everything." Forbes, October 26. https://www.forbes.com/sites/brendancoffey/ 
2011/10/26/the-four-companies-that-control-the-147companies-that-own-everything/\#7e0a3c93685b.

[7] Drucker, Peter F. 2001. The Essential Drucker. New York: Harper Collings Publishers.

[8] Dugin, Alexander. 2013. La Cuarta Teoría Política. Barcelona: Ediciones Nueva República.

[9] Dugin, Alexandr. 2018. "Uprising in France The Anatomy of Populism and Challenging the Matrix." Fort Russ News, December 4. https: //www.fort-russ.com/2018/12/dugin-uprising-in-francethe-anatomy-of-populism-and-challenging-the-matrix/

[10] Gilets Jaunes. 2019. "Gilets Jaunes - Coordination Nationale des Régions." Last accessed March 9, 2019. https: //www.giletsjaunes-coordination.fr/

[11] IDEA. 2019. "Voter Turnout. France." International IDEA - Institute for Democracy and Electoral Assistance. Last accessed March 9, 2019. https://www.idea.int/data-tools/ question-countries-view/522/86/ctr

[12] Kagarlitsky, Boris. 2018. "The Spontaneous Politics of the Masses: Slavoj Žižek and the Yellow Vests." CounterPunch, January 7. https://www.counterpunch.org/2019/01/07/ the-spontaneous-politics-of-the-masses-slavoj-zizek-andthe-yellow-vests/.

[13] Karlin, Anatoly. 2017. "Dugin, Putin's 39th Brain." The Unz Review, January 21. http://www.unz.com/akarlin/ dugin-putins-39th-brain/

[14] Le Pen, Marie. 2015. "Régionales 2015: pour Marine Le Pen, «le clivage politique sépare désormais mondialistes et patriotes»" [Video]. Le Monde December 13. https://www.lemonde.fr/electionsregionales-2015/video/2015/12/13/marine-le-pen-leclivage-n-est-plus-gauche-et-droite-mais-mondialistes-etpatriotes_4831014_4640869.html

[15] Maréchal, Samuel. 1996. Ni Droite, ni Gauche - Français!: Contre la Pensée Unique, L'autre Politique. Paris: Premiere Ligne.

[16] Mélenchon, Jean-Luc. 2018. "«Voici la nouvelle France» - Discours de Jean-Luc Mélenchon à Épinay-sur-Seine" [VIDEO]. L'Ére du Peuple, November 18. https:// melenchon.fr/2018/11/18/video-voici-la-nouvelle-francediscours-de-jean-luc-melenchon-a-epinay-sur-seine/

[17] Ministère de l'intérieur. 2017. "Résultats de l'élection présidentielle 2017." Ministère de l'interieur, May 7. https://www.interieur.gouv.fr/Elections/Les-resultats/ Presidentielles/elecresult__presidentielle-2017/(path)/ presidentielle-2017/FE.html.

[18] Negri, Toni. 2018a. "L'insurrezione Francese." Euronomade, December 4, http://www.euronomade.info/?p= 11351

[19] Negri, Toni. 2018b. "Gilets jaunes: un contropotere?" Euronomade, December 21. http: //www.euronomade.info/?p=11461

[20] Negri, Antonio, and Michael Hardt. 2001. Império. São Paulo: Editora Record.

[21] Negri, Antonio, and Michael Hardt. 2004. Multitud: Guerra y democracia en la era del Imperio. Barcelona: Debate.

[22] Negri, Antonio, and Cesare Casarino. 2012. Elogio de lo Común: Conversaciones sobre Filosofía y Política. Barcelona: Paidós.

[23] Open Revolt. n.d. "About OR - Open Revolt!" Last accessed March 9, 2019. https://openrevolt.info/about/

[24] Pena, Paulo, David Mandim, and Paula Sofia Luz. 2018. "Porque falharam (desta vez) os 'coletes amarelos' em Portugal." Diário de Notícias, December 21. https://www.dn.pt/pais/interior/porque-falharam-destavez-os-coletes-amarelos-em-portugal-10352887.html

[25] Savitz, Eric. 2011. "Retort: The 147 Companies That Run The World? They're You." Forbes, October 24. https://www.forbes.com/sites/ericsavitz/2011/10/24/ retort-the-147-companies- that-run-the-world-theyre-you/ \#75cda7d47ebf

[26] Steinmann, Luca. 2018. "Alexander Dugin, il 'Rasputin' di Putin, arriva in Italia." Huffington Post - Italia, June 22. https://www.huffingtonpost.it/2018/06/22/alexanderdugin-il-rasputin-di-putin-arriva-in-italia_a_23464868/

[27] Tsé-Tung, Mao. 1990. "The Law of the Unity of Contradictions [On Contradiction]". In Mao Zedong on Dialectical Materialism, edited by Nick Knight, 154-229. New York: N.E. Sharpe, Inc.

[28] Upbin, Bruce. 2011. "The 147 Companies That Control Everything." Forbes, October 22. https: //www.forbes.com/sites/bruceupbin/2011/10/22/the147-companies-that-control-everything/\#693d8eb75105.

[29] Zadyraka, Volodymyr. 2015. "A critique of the Boris Kagarlitsky, the 'Red Putinist'." Worker's Liberty, May 5. https://www.workersliberty.org/story/2017-07-26/ critique-boris-kagarlitsky-red-putinist

[30] Żižek, Slavoj. 2009. First as Tragedy, Then as Farce. New York: Verso.

[31] Žižek, S Slavoj. 2018a. "The yellow vest protesters revolting against centrism mean well - but their left wing populism won't change French politics." The Independent, December 17. https://www.independent.co.uk/voices/ yellow-vest-protests-france-paris-gilets-jaunes-macronfuel-tax-minimum-wage-populism-a8686586.html.

[32] Zižek, Slavoj. 2018b. "How Mao would have evaluated the Yellow Vests." RT, December 21. https://www.rt.com/oped/447155-zizek-yellow-vests-france/

[33] Zižek, Slavoj. 2008c. Violence: Six Sideways Reflections. New York: Picador

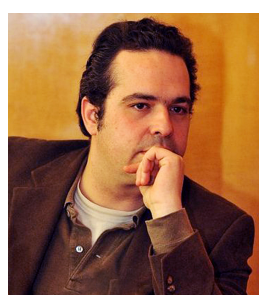

Rodrigo Almeida Sousa born in Johannesburg (1975), R. A. Sousa is a writer and academic researcher at CITCEM (University of Porto) with an interdisciplinary background: Philosophy (BA/Catholic University of Portugal), Literary Theory (MA/University of Lisbon) and Audiovisual Communication (PhD/Complutense University of Madrid Outstanding Doctorate Award 2015-2016). In his research, he usually relates cultural dynamics, trends, historical-social events with media supports and communicational paradigms, with a view to examining contemporary dilemmas, particularly regarding creativity, communication and social discourses. Lately, he has been focusing on digital cultures, sub-cultures and movements, generated and/or fostered within the post-truth environment and their reflection on audiovisual narratives (news, opinion, entertainment, film, TV, arts). As a writer/screenwriter, he has authored two successful children's books (My School Would Make a Movie, 2011; Louie The Cootie, 2013) and award-winning short and full-length movie scripts (e.g. Gesto, A. B. Correia, 2011; Cova, L. Alves, 2011) 